\title{
Thyroid hormone uptake in cultured rat anterior pituitary cells: effects of energy status and bilirubin
}

\author{
F W J S Wassen, E P C M Moerings, H van Toor, G Hennemann \\ and $\mathbf{M}$ E Everts \\ Department of Internal Medicine III, Erasmus University Medical School, Rotterdam, The Netherlands \\ (Requests for offprints should be addressed to M E Everts, Department of Veterinary Anatomy and Physiology, Division of Physiology, Postbox 80157, \\ 3508 TD Utrecht, The Netherlands; Email: m.everts@vet.uu.nl)
}

\begin{abstract}
Transport of thyroxine $\left(T_{4}\right)$ into the liver is inhibited in fasting and by bilirubin, a compound often accumulating in the serum of critically ill patients. We tested the effects of chronic and acute energy deprivation, bilirubin and its precursor biliverdin on the 15 -min uptake of $\left[{ }^{125} \mathrm{I}\right]$ triiodothyronine $\left(\left[{ }^{125} \mathrm{I}\right] \mathrm{T}_{3}\right)$ and $\left[{ }^{125} \mathrm{I}\right] \mathrm{T}_{4}$ and on TSH release in rat anterior pituitary cells maintained in primary culture for 3 days. When cells were cultured and incubated in medium without glucose and glutamine to induce chronic energy deprivation, the ATP content was reduced by $45 \%$ $(P<0 \cdot 05)$ and $\left[{ }^{125} \mathrm{I}\right] \mathrm{T}_{3}$ uptake by $13 \%(\mathrm{NS})$, but $\mathrm{TSH}$ release was unaltered. Preincubation $(30 \mathrm{~min})$ and incubation $(15 \mathrm{~min})$ with $10 \mu \mathrm{M}$ oligomycin reduced ATP
\end{abstract}

content by $51 \% \quad(P<0 \cdot 05)$ and $53 \%(P<0 \cdot 05)$ under energy-rich and energy-poor culture conditions respectively; $\left[{ }^{125} \mathrm{I} \mathrm{T}_{3}\right.$ uptake was reduced by $66 \% \quad(P<0 \cdot 05)$ and $64 \% \quad(P<0 \cdot 05)$. Neither bilirubin nor biliverdin (both $1-200 \mu \mathrm{M}$ ) affected uptake of $\left[{ }^{125} \mathrm{I}^{1} \mathrm{~T}_{3}\right.$ or $\left[{ }^{125} \mathrm{I}\right] \mathrm{T}_{4}$. Bilirubin $(1-50 \mu \mathrm{M})$ did not alter basal or TRH-induced TSH release. In conclusion, the absence of inhibitory effects of chronic energy deprivation and bilirubin on thyroid hormone uptake by pituitary cells supports the view that the transport is regulated differently than that in the liver.

Journal of Endocrinology (2000) 165, 599-606

\section{Introduction}

Non-thyroidal illness (NTI) is associated with multiple alterations in serum thyroid hormone parameters. Most prominent are the low serum tri-iodothyronine $\left(\mathrm{T}_{3}\right)$ and increased reverse $T_{3}$ concentrations, together with inappropriately low concentrations of serum thyroidstimulating hormone (TSH) (Wartofsky \& Burman 1982, Docter et al. 1993). Apart from fasting, conditions that may result in NTI include chronic renal failure and liver disease (Wartofsky \& Burman 1982, Kaptein 1996).

As the liver is the major site of $\mathrm{T}_{3}$ production in humans (Hennemann 1986), the low serum $\mathrm{T}_{3}$ during NTI can be ascribed to a reduced type I deiodinase activity (Harris et al. 1978, Kohrle et al. 1991), in addition to a reduced transport of thyroxine $\left(\mathrm{T}_{4}\right)$ into the liver (De Jong et al. 1992, 1994, Vos et al. 1995). The diminished tissue uptake of $\mathrm{T}_{4}$ in calorie-deprived humans (Van Der Heyden et al. 1986) seems to be secondary to the reduction in cellular ATP (De Jong et al. 1994). The reduction in $T_{4}$ transport into the liver in chronic renal failure or liver disease can be explained by inhibitory effects of compounds that accumulate in the serum, such as furan fatty acids, indoxyl sulphate or bilirubin (Lim et al. 1993a, b). Conversely, despite the observed alterations in serum thyroid hormone parameters in NTI, there is no change in expression of $\mathrm{T}_{3}$-regulated genes in the liver, indicating the maintenance of tissue euthyroidism (Chamba et al. 1996).

Because serum TSH does not increase, in spite of the low serum $\mathrm{T}_{3}$ in fasting or NTI, we suggested in a previous study that $T_{3}$ transport into the pituitary is regulated differently from that in liver (Everts et al. 1996). Indeed, in contrast to the effects on $\mathrm{T}_{4}$ transport observed in hepatocytes ( $\operatorname{Lim}$ et al. 1993a), the furan fatty acid 3-carboxy-4-methyl-5-propyl-2-furanpropanoic acid (CMPF) and indoxyl sulphate - compounds accumulating in serum of patients with chronic renal failure - did not affect uptake of $\mathrm{T}_{3}$ and $\mathrm{T}_{4}$ into pituitary cells (Everts et al. 1995a).

This hypothesis was further elaborated in the present study. We have investigated the effects of chronic energy deprivation and bilirubin - a compound often accumulating in serum of patients with liver disease (Lim et al. $1993 b)$ - and its precursor, biliverdin, on the uptake of $\mathrm{T}_{3}$ and $\mathrm{T}_{4}$ and on basal and thyrotrophin-releasing hormone (TRH)-stimulated TSH release in cultured anterior pituitary cells. To induce chronic energy deprivation, we cultured anterior pituitary cells from fed rats in medium 
lacking glucose and glutamine. The effects of bilirubin and its precursor biliverdin were tested by adding the compounds to the incubation medium at concentrations (relative to albumin) in the range from those present in normal serum to greater than those present in serum of patients with liver disease.

\section{Materials and Methods}

\section{Animals}

All experiments were performed using male Wistar rats, weighing $200-220 \mathrm{~g}$. The animals had free access to food and water and were kept in a controlled environment $\left(21^{\circ} \mathrm{C}\right)$ with constant day length $(12 \mathrm{~h})$.

\section{Pituitary cell culture}

Animals (12-16 for each experiment) were killed between 0900 and $0930 \mathrm{~h}$ by decapitation. The pituitary glands were removed within $5 \mathrm{~min}$, the neurointermediate lobe was discarded, and the anterior lobes were collected in calcium- and magnesium-free Hank's Balanced Salt Solution, supplemented with $10 \mathrm{~g} / 1$ human serum albumin, penicillin $\left(10^{5} \mathrm{U} / \mathrm{l}\right)$, amphotericin $\mathrm{B}(0 \cdot 5 \mathrm{mg} / \mathrm{l})$, and sodium bicarbonate $(0 \cdot 4 \mathrm{~g} / \mathrm{l})$. Anterior pituitary cells were dissociated with dispase (final concentration $2 \cdot 4 \times 10^{3} \mathrm{U} / 1$ ), as previously described (Everts et al. 1993, 1994a). From each pituitary, 1-2 $\times 10^{6}$ cells were obtained and the viability of the cells as determined by trypan blue exclusion was greater than $90 \%$.

The cells were cultured at $37^{\circ} \mathrm{C}$ in a water-jacketed incubator with $5 \% \mathrm{CO}_{2}$ at a density of approximately $5 \times 10^{5}$ cells/well in 48 -well culture dishes. The cells had attached to the wells after 2 days of culture. On day 3 , the cells were used for experiments. The culture medium consisted of Minimal Essential Medium with Earle's salts (MEM) supplemented with non-essential amino acids, sodium pyruvate $(1 \mathrm{mM}), 10 \%$ fetal calf serum, penicillin $\left(10^{5} \mathrm{U} / \mathrm{l}\right)$, amphotericin B $(0 \cdot 5 \mathrm{mg} / \mathrm{l})$, glucose $(6 \cdot 25 \mathrm{mM})$, L-glutamine $(2 \mathrm{mM})$ and sodium bicarbonate $(2 \cdot 2 \mathrm{~g} / 1$ pH 7-4) (Everts et al. 1993, 1994a). For culture under energy-poor conditions, the culture medium was based on MEM without glucose, supplemented with non-essential amino acids, sodium pyruvate $(1 \mathrm{mM}), 10 \%$ fetal calf serum, penicillin $\left(10^{5} \mathrm{U} / \mathrm{l}\right)$, amphotericin $\mathrm{B}(0.5 \mathrm{mg} / \mathrm{l})$ and sodium bicarbonate $(2 \cdot 2 \mathrm{~g} / 1 \mathrm{pH} 7 \cdot 4)$.

\section{Cellular uptake of $\left[{ }^{125} I\right] T_{3}$ and $\left[{ }^{125} I\right] T_{4}$}

Cellular uptake experiments were performed as described previously (Everts et al. 1993, 1994a). Briefly, cells were cultured for 3 days at a density of approximately 500000 cells/well. Blank wells contained only culture medium. The culture medium was removed and cells were preincubated in incubation medium. This medium was identical to the culture medium, except that the fetal calf serum was replaced by $0.5 \%$ BSA when $\left[{ }^{125} \mathrm{I}\right] \mathrm{T}_{3}$ (50 000 c.p.m.; 50 pM) was measured, and by $0 \cdot 1 \%$ BSA in case of $\left[{ }^{125} \mathrm{I}_{\mathrm{T}}(100000\right.$ c.p.m.; $175 \mathrm{pM})$ uptake. Furthermore, $\mathrm{NaHCO}_{3}(25 \mathrm{mM})$ was replaced by $N$-2-hydroxyethyl-piperazine- $N^{\prime}-2$-ethanesulphonic acid (HEPES $8.9 \mathrm{mM}$ ), piperazine- $N, N^{\prime}$-bis(2-ethanesulphonic acid) (PIPES $10 \cdot 6 \mathrm{mM}$ ), and N,N-bis(2hydroxyethyl)-2-aminoethane-sulphonic acid (BES $11.2 \mathrm{mM})$. To study the effects of acute ATP depletion on $\left[{ }^{125} \mathrm{I}\right] \mathrm{T}_{3}$ uptake, we carried out preincubation $(0 \cdot 5 \mathrm{ml})$ for $30 \mathrm{~min}$ in the absence or presence of oligomycin $(10 \mu \mathrm{M})$, then the preincubation medium was discarded and cells were incubated for $15 \mathrm{~min}$ in $0 \cdot 25 \mathrm{ml}$ medium containing $\left[{ }^{125} \mathrm{I}_{3} \mathrm{~T}_{3}\right.$ without or with $10 \mu \mathrm{M}$ oligomycin. Both preincubation and incubation were performed in a $37^{\circ} \mathrm{C}$ incubation chamber on a rotating device. Experiments to test the effects of bilirubin $(1-200 \mu \mathrm{M})$ and biliverdin $(1-200 \mu \mathrm{M})$ on $\left[{ }^{125} \mathrm{I}\right] \mathrm{T}_{3}$ and $\left[{ }^{125} \mathrm{I}\right] \mathrm{T}_{4}$ uptake were performed as described above, except that, after preincubation $(0.25 \mathrm{ml}, 30 \mathrm{~min})$ without or with bilirubin or biliverdin, incubation was started by the addition of $10 \mu \mathrm{l}\left[{ }^{125} \mathrm{I}\right] \mathrm{T}_{3}$ or $\left[{ }^{125} \mathrm{I}\right] \mathrm{T}_{4}$ directly to the wells.

After incubation, the medium was removed and cells were washed once with $1 \mathrm{ml}$ ice-cold saline in order to remove unbound tracer. Cells were dissolved in $1 \mathrm{ml}$ $0 \cdot 1 \mathrm{M} \mathrm{NaOH}$ and were counted for iodine-125 activity in a 16-channel gamma-counter (NE 1600, Nuclear Enterprises, Edinburgh, Scotland). The amount of $\left[{ }^{125} \mathrm{I}\right] \mathrm{T}_{3}$ or $\left[{ }^{125} \mathrm{I}\right] \mathrm{T}_{4}$ taken up by the cells was expressed as a percentage of the total radioactivity added (percentage dose). The procedure described above was also applied to incubations without cells. All results were corrected for radioactivity retained in the blanks.

\section{TSH release and cellular content}

The culture medium was removed, centrifuged $(2000 \times \boldsymbol{g})$ and frozen until required for hormone determination. The incubation medium was identical to the culture medium, except that the fetal calf serum was replaced by $0.5 \%$ BSA. Cells were preincubated for $2 \mathrm{~h}$ in the absence or presence of bilirubin $(1-200 \mu \mathrm{M})$. Thereafter, this medium was discarded and cells were incubated for $2 \mathrm{~h}$ with the same concentrations bilirubin without or with TRH (100 nM). After incubation, the medium was removed, centrifuged $(2000 \times \boldsymbol{g})$ and stored at $-20{ }^{\circ} \mathrm{C}$.

To determine the TSH content of the cells, $0.5 \mathrm{ml}$ incubation medium was added to the wells. The cells were scraped from the wells with a rubber policeman and the wells were sonicated for $2 \times 30 \mathrm{~s}$. The extracts were removed and the wells were washed with $0.5 \mathrm{ml}$ medium. The two fractions were combined (volume of cell extract $1 \cdot 0 \mathrm{ml})$, centrifuged $(2000 \times \boldsymbol{g})$ at room temperature and the supernatant was frozen until further analysis. 
Table 1 Effects of chronic or acute energy depletion on ATP content, $\left[{ }^{125} \mathrm{I}\right] \mathrm{T}_{3}$ uptake and DNA content of anterior pituitary cells

\begin{tabular}{|c|c|c|c|c|}
\hline & $\begin{array}{l}\text { ATP content } \\
(\mu \mathrm{g} / \text { well })\end{array}$ & $\begin{array}{l}{\left[{ }^{125}{ }^{1}\right] T_{3} \text { uptake }} \\
\text { (\% dose/well) }\end{array}$ & $\begin{array}{l}\text { DNA content } \\
\text { (ng/well) }\end{array}$ & $\begin{array}{l}{\left[{ }^{125}{ }\right]_{T_{3}} \text { uptake }} \\
(\% \text { dose } / \mu g \text { DNA })\end{array}$ \\
\hline \multicolumn{5}{|c|}{ Experimental conditions } \\
\hline \multicolumn{5}{|c|}{ Normal culture conditions } \\
\hline Controls & $0 \cdot 495 \pm 0.031(9)$ & $1 \cdot 49 \pm 0 \cdot 07(12)$ & $2475 \pm 35(3)$ & $0 \cdot 60 \pm 0.03(12)$ \\
\hline$+10 \mu \mathrm{M} \mathrm{T}_{3}$ & $0 \cdot 431 \pm 0 \cdot 027(8)$ & $0.76 \pm 0.06(12)^{*}$ & $2476 \pm 158$ & $0 \cdot 31 \pm 0 \cdot 02(12)^{*}$ \\
\hline$+10 \mu \mathrm{M}$ oligo & $0 \cdot 244 \pm 0.042(9)^{*}$ & $0.51 \pm 0.08(12)^{*}$ & $2791 \pm 165$ & $0 \cdot 18 \pm 0 \cdot 03(12)^{*}$ \\
\hline \multicolumn{5}{|c|}{ Culture without glucose and glutamine } \\
\hline Controls & $0 \cdot 272 \pm 0 \cdot 013(6) \dagger$ & $1 \cdot 29 \pm 0 \cdot 07(12)$ & $2133 \pm 99(3) \dagger$ & $0 \cdot 61 \pm 0.03(12)$ \\
\hline$+10 \mu \mathrm{M} \mathrm{T}_{3}$ & $0 \cdot 291 \pm 0.034(8) \dagger$ & $0.55 \pm 0.05(12)^{*} \dagger$ & $2014 \pm 59(3)$ & $0.27 \pm 0.03(12)^{*}$ \\
\hline$+10 \mu \mathrm{M}$ oligo & $0 \cdot 128 \pm 0 \cdot 064(9)$ & $0 \cdot 47 \pm 0 \cdot 14(12)^{*}$ & $1718 \pm 59(3)^{*} \dagger$ & $0.27 \pm 0.08(12)^{*}$ \\
\hline
\end{tabular}

Data represent the means \pm S.E. (number of observations). ATP content and $\left[{ }^{125} 1\right] T_{3}$ uptake were measured in three or four experiments and DNA content in one experiment. Fifty percent of the anterior pituitary cells (500 000 cells/well) were cultured for 3 days in medium containing $10 \%$ fetal calf serum (normal culture conditions) and $50 \%$ were cultured in medium lacking glucose and glutamine but with $10 \%$ fetal calf serum. Cells were preincubated (30 min) in the absence or presence of oligomycin (oligo), and incubation $\left(15 \mathrm{~min}\right.$ ) was performed with [ $\left.{ }^{125} \mathrm{I}\right] \mathrm{T}_{3}$ without or with $10 \mu \mathrm{M} \mathrm{T}_{3}$ or oligomycin. ${ }^{*} P<0 \cdot 05$ compared with respective controls; $\uparrow P<0 \cdot 05$ compared with normal culture conditions.

\section{TSH determination}

TSH in incubation media and cell extracts was measured by RIA (Everts et al. 1993). Addition of bilirubin (5 and $200 \mu \mathrm{M})$ to the TSH standards did not alter the standard curve.

\section{Free hormone concentration}

Calculation of the free $T_{3}\left(\mathrm{fT}_{3}\right)$ or free $\mathrm{T}_{4}\left(\mathrm{fT}_{4}\right)$ concentrations was based on determination of the free hormone fractions by equilibrium dialysis (Sterling \& Brenner 1966). As shown previously (Everts et al. 1993), the $\mathrm{fT}_{3}$ fraction was not altered by $10 \mu \mathrm{M} \mathrm{T} \mathrm{T}_{3}$ or oligomycin.

\section{ATP and DNA determination}

The cellular ATP content was determined in perchloric acid (0.2 M) extracts with the Lumac AEC Kit (Lumac, Landgraaf, The Netherlands). The DNA content of the cells was determined using a modification (Everts et al. 1994a) of the fluorescence technique described by Downs \& Wilfinger (1983).

\section{Chemicals and isotopes}

All solutions used for cell isolation and cell culture were obtained from GIBCO Europe (Breda, The Netherlands), with the exception of human serum albumin (Central Laboratory of the Red Cross Blood Transfusion Service, Amsterdam, The Netherlands), dispase (grade II; Boehringer, Mannheim, Germany) and amphotericin B (Fungizone, Bristol-Myers Squibb, Woerden, The Netherlands). Culture dishes (48 wells) were from Costar (Cambridge, MA, USA). PIPES, HEPES, BES, BSA (fraction $\mathrm{V}$ ), oligomycin, bilirubin and biliverdin were all from Sigma (St Louis, MO, USA). $\mathrm{L}^{-\mathrm{T}_{3}}\left(\mathrm{~T}_{3}\right)$ was from
Henning Berlin Gmbh (Berlin, Germany) and TRH was from Hoechst AG (Frankfurt am Main, Germany). $\left[3^{\prime}, 5^{\prime}{ }_{-}{ }^{125} \mathrm{I}\right] \mathrm{T}_{4}(1500 \mu \mathrm{Ci} / \mu \mathrm{g})$ and $\left[3^{\prime}-{ }^{125} \mathrm{I}^{2} \mathrm{~T}_{3}(3070 \mu \mathrm{Ci} /\right.$ $\mu \mathrm{g})$ were obtained from Amersham International (Aylesbury, Bucks, UK). Reagents for the rat TSH RIA were kindly provided by the NIDDK (Bethesda, MD, USA). Sephadex LH-20 and G-25 were from Pharmacia (Uppsala, Sweden). All other reagents were of the highest purity available.

\section{Statistics}

Results are presented as means \pm S.E. The statistical significance of the effects of the compounds tested and of glucose deprivation on TSH release, $\left[{ }^{125} \mathrm{I}\right] \mathrm{T}_{3}$ and $\left[{ }^{125} \mathrm{I}\right] \mathrm{T}_{4}$ uptake, $\mathrm{fT}_{3}$ and $\mathrm{fT}_{4}$ fractions, and cellular ATP and DNA content was evaluated by Student's $t$-test for unpaired observations or by one-way analysis of variance and Duncan's test for a repeated measure design. Differences were considered significant at $P<0 \cdot 05$.

\section{Results}

Effects of energy deprivation

Culture of pituitary cells for 3 days without glucose and glutamine did not affect TSH release $(22 \cdot 44 \pm 0.85 \mathrm{ng}$, $n=44$, compared with $22 \cdot 60 \pm 1 \cdot 11 \mathrm{ng}, n=44)$. However, the cellular ATP content was reduced by $45 \%(P<0 \cdot 05)$ compared with that in cells cultured in the normal culture medium (Table 1).

As further shown in Table 1, chronic energy deprivation did not alter the 15 -min uptake of $\left[{ }^{125} \mathrm{I}\right] \mathrm{T}_{3}$. Exposure to $10 \mu \mathrm{M}$ unlabelled $\mathrm{T}_{3}$ significantly reduced $\left[{ }^{125} \mathrm{IT}_{3}\right.$ uptake under both normal $(49 \% ; P<0 \cdot 05)$ and energy-poor $(57 \% ; P<0.05)$ culture conditions. Chronic 
energy deprivation only slightly affected the DNA content of the wells. When $\left[{ }^{125} \mathrm{I}\right] \mathrm{T}_{3}$ uptake was expressed per $\mu \mathrm{g}$ DNA, the uptake values for normal and energy-deprived cells were precisely the same.

Preincubation (30 $\mathrm{min})$ and incubation $(15 \mathrm{~min})$ with $10 \mu \mathrm{M}$ oligomycin reduced the cellular ATP content by $51 \%(P<0 \cdot 05)$ when added under energy-rich culture conditions and by $53 \%(P<0 \cdot 05)$ when the conditions were energy-poor. This was associated with significant reductions in $\left[{ }^{125} \mathrm{I}_{\mathrm{T}}\right.$ transport: of $66 \%(P<0 \cdot 05)$ and $64 \%(P<0 \cdot 05)$ respectively (Table 1$)$. Under energy-poor culture conditions only, oligomycin slightly reduced the DNA concentrations (Table 1).

\section{Effects of bilirubin and biliverdin}

Free hormone fraction $\mathrm{The}_{\mathrm{f}} \mathrm{T}_{3}$ and $\mathrm{fT}_{4}$ fractions were determined in medium with $0.5 \%$ and $0.1 \% \mathrm{BSA}$, respectively. The added concentrations of the compounds were expressed relative to albumin (molar ratios of from 0.06 to $2 \cdot 40$ ) because bilirubin and biliverdin both bind to albumin. The $\mathrm{fT}_{3}$ fraction was $3.57 \pm 0.07 \%(n=8)$, and the $\mathrm{fT}_{4}$ fraction was $3 \cdot 39 \pm 0 \cdot 26 \%(n=8)$ - values in good agreement with previous findings (Everts et al. 1995a). Greater concentrations of bilirubin had no effect on the $\mathrm{fT}_{3}$ fraction, whereas the $\mathrm{fT}_{4}$ fraction was increased at bilirubin:albumin ratios of 0.60 and 2.40 respectively (Fig. 1a). In contrast, biliverdin did not affect the $\mathrm{fT}_{3}$ or the $\mathrm{fT}_{4}$ fraction (Fig. 1b).

$\left[{ }^{125} \mathrm{I}\right] \mathrm{T}_{3}$ and $\left[{ }^{125} \mathrm{I}\right] \mathrm{T}_{4}$ uptake The effects of bilirubin and biliverdin on plasma membrane uptake of $\left[{ }^{125} \mathrm{I}\right] \mathrm{T}_{3}$ and $\left[{ }^{125} \mathrm{I}\right] \mathrm{T}_{4}$ were determined in short-term incubations (15 min). Neither the uptake of $\left[{ }^{125} \mathrm{I} \mathrm{T}_{3}\right.$ nor that of $\left[{ }^{125} \mathrm{I}\right] \mathrm{T}_{4}$, both expressed per $\mathrm{pM}$ free hormone, were altered in presence of bilirubin (Fig. 2a). The effect of biliverdin on $\left[{ }^{125} \mathrm{I}\right] \mathrm{T}_{3}$ and $\left[{ }^{125} \mathrm{I}\right] \mathrm{T}_{4}$ uptake was determined in a similar way. The uptake of the two tracers was not altered by biliverdin (Fig. 2b).

Basal TSH release The effect of bilirubin on basal TSH release was tested in experiments with $2 \mathrm{~h}$ preincubation, followed by $2 \mathrm{~h}$ incubation. The results of the incubation period are shown in Fig. 3, in which data are expressed as percentages of the control value. The concentrations of bilirubin tested $(1,5,50$ and $200 \mu \mathrm{M})$ correspond to molar ratios with albumin of $0 \cdot 01,0 \cdot 06,0.60$ and 2.40 respectively. The lower bilirubin concentrations $(1-50 \mu \mathrm{M})$ did not affect basal TSH release, but $200 \mu \mathrm{M}$ bilirubin resulted in a significant increase $(38 \% ; P<0 \cdot 05)$. DNA content after $4 \mathrm{~h}$ of incubation with $200 \mu \mathrm{M}$ bilirubin was significantly lower than that of the controls $(1.31 \pm 0.03 \mu \mathrm{g}$ DNA/well, $n=3$, compared with $1 \cdot 80 \pm 0 \cdot 05 \mu \mathrm{g}$ DNA/ well, $n=6$, respectively; $P<0 \cdot 001)$.

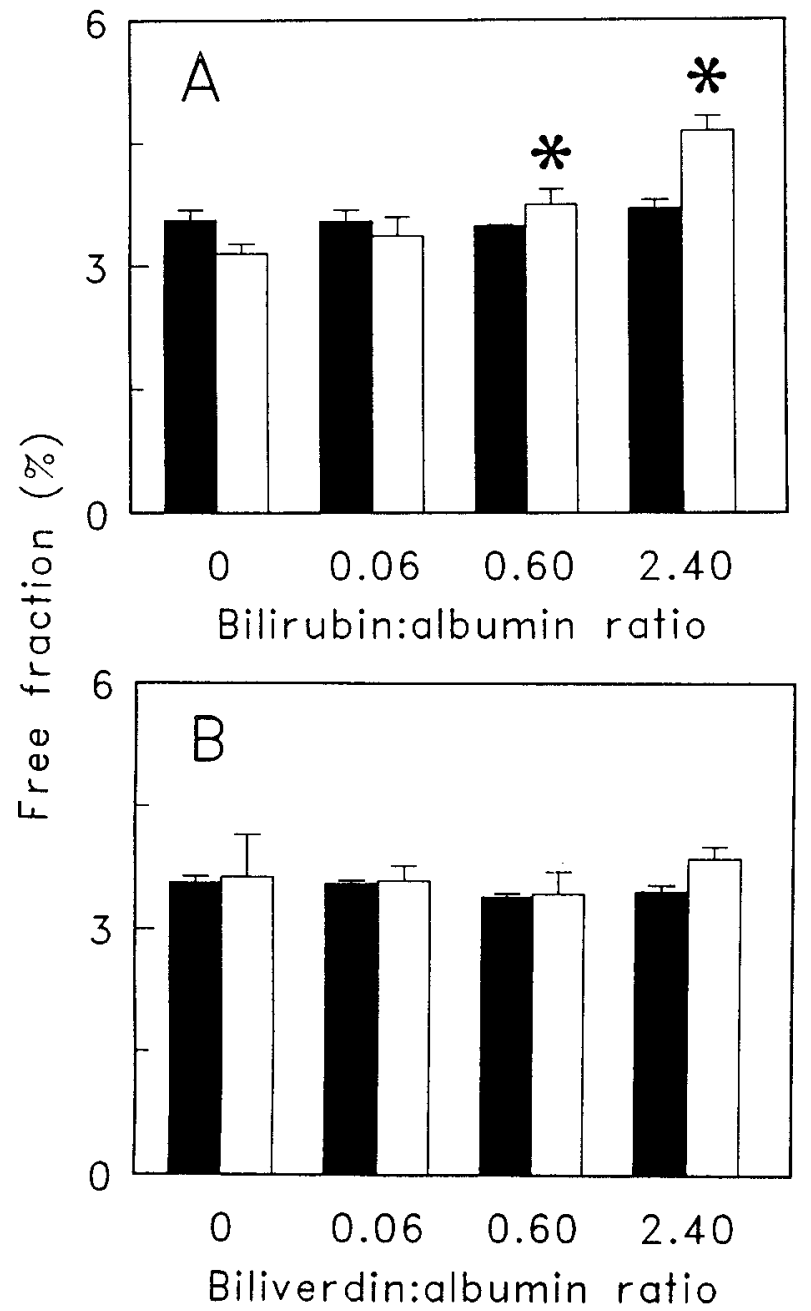

Figure 1 Effects of bilirubin (a) and biliverdin (b) on the $\mathrm{fT}_{3}($ and $\mathrm{fT}_{4}(\square)$ fractions, determined in medium with $0.5 \%$ BSA for $\left[{ }^{125}{ }^{12}\right] \mathrm{T}_{3}$ and with $0 \cdot 1 \% \mathrm{BSA}$ for $\left[{ }^{125} \mathrm{I}\right] \mathrm{T}_{4}$. The $\mathrm{fT}_{3}$ and $\mathrm{fT}_{4}$ fractions were determined by equilibrium dialysis. The added bilirubin and biliverdin concentrations are expressed relative to albumin (bilirubin:albumin ratio). Bars show the mean of four observations from two experiments. ${ }^{*} P<0 \cdot 05$ compared with no additions.

TRH-induced TSH release The effect of bilirubin on TRH-induced TSH release was determined during short $(2 \mathrm{~h})$ exposure to TRH after preincubation for $2 \mathrm{~h}$ without or with bilirubin $(5-200 \mu \mathrm{M})$ (Table 2). Incubation with TRH alone stimulated TSH release by $200 \%(P<0 \cdot 05)$. TRH-induced TSH release was not altered significantly by the lower bilirubin concentrations $(5-50 \mu \mathrm{M})$, but $200 \mu \mathrm{M}$ bilirubin produced a large increase $(P<0 \cdot 05 ; n=6)$. Cellular TSH content was not altered after addition of TRH and 5 or $50 \mu \mathrm{M}$ bilirubin, but in the presence of $200 \mu \mathrm{M}$ bilirubin a significant decline was observed. The total TSH content showed no significant change with any of the additions. 


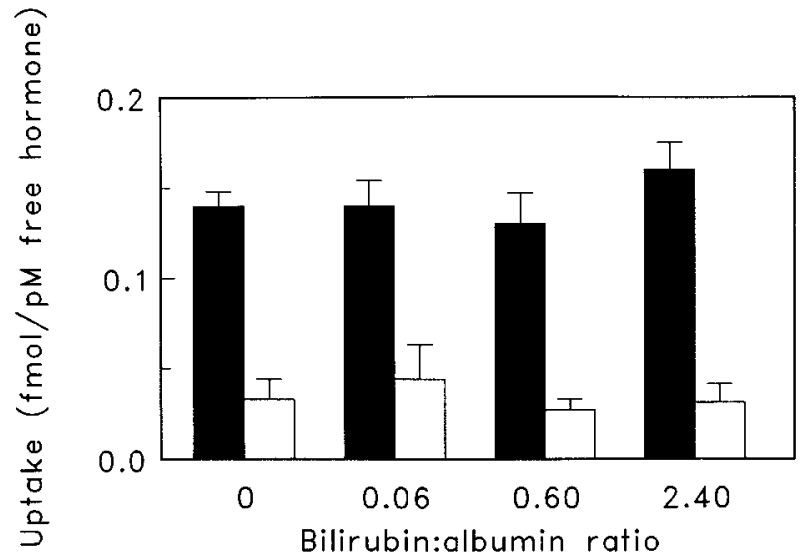

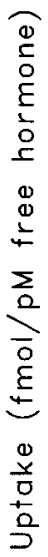

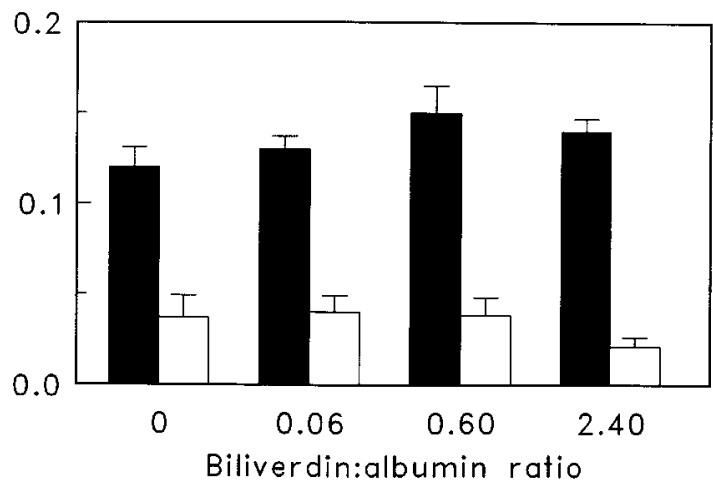

Figure 2 Uptake of $\left[{ }^{125} \mathrm{I}\right] \mathrm{T}_{3}(\boldsymbol{\square})$ and $\left[{ }^{125} \mathrm{I}\right] \mathrm{T}_{4}(\square)$ by anterior pituitary cells in the presence of bilirubin (a) or biliverdin (b). Cells were cultured for 3 days at a density of 500000 cells/well. Thereafter, culture medium was removed and cells were preincubated for $30 \mathrm{~min}$ in incubation medium containing $0.5 \%$ BSA when $\left[{ }^{125} \mathrm{ITT}_{3}\right.$ uptake was measured and $0 \cdot 1 \% \mathrm{BSA}$ in the case of $\left[{ }^{125} \mathrm{I}\right] \mathrm{T}_{4}$, in the absence or presence of bilirubin or biliverdin $(1-200 \mu \mathrm{M})$. Incubation was started by the addition of $10 \mu \mathrm{l}\left[{ }^{125} \mathrm{I}\right] \mathrm{T}_{3}$ (50 000 c.p.m.) or $\left[{ }^{125} \mathrm{I}\right] \mathrm{T}_{4}$ (100 000 c.p.m.) directly to the preincubation medium. The 15-min uptake of the two tracers is expressed per $\mathrm{pM}$ free hormone and the concentrations bilirubin and biliverdin are expressed relative to albumin. Bars represent the mean \pm S.E. of from five to nine observations from two experiments for $\left[{ }^{125} \mathrm{I}\right] \mathrm{T}_{4}$ and three for $\left[{ }^{125} \mathrm{I}\right] \mathrm{T}_{3}$ uptake.

\section{Discussion}

We have previously evaluated the role of the liver and pituitary in the maintenance of the low serum $\mathrm{T}_{3}$ and normal TSH concentrations in NTI and fasting (Everts et al. 1996). In that review, we postulated that the plasma membrane thyroid hormone transport mechanism is regulated differently in these two tissues, and we provided experimental evidence for this idea from both in vivo and in vitro experiments. The hypothesis is further elaborated in the present study on thyroid hormone transport in cultured rat anterior pituitary cells. Although this exper-

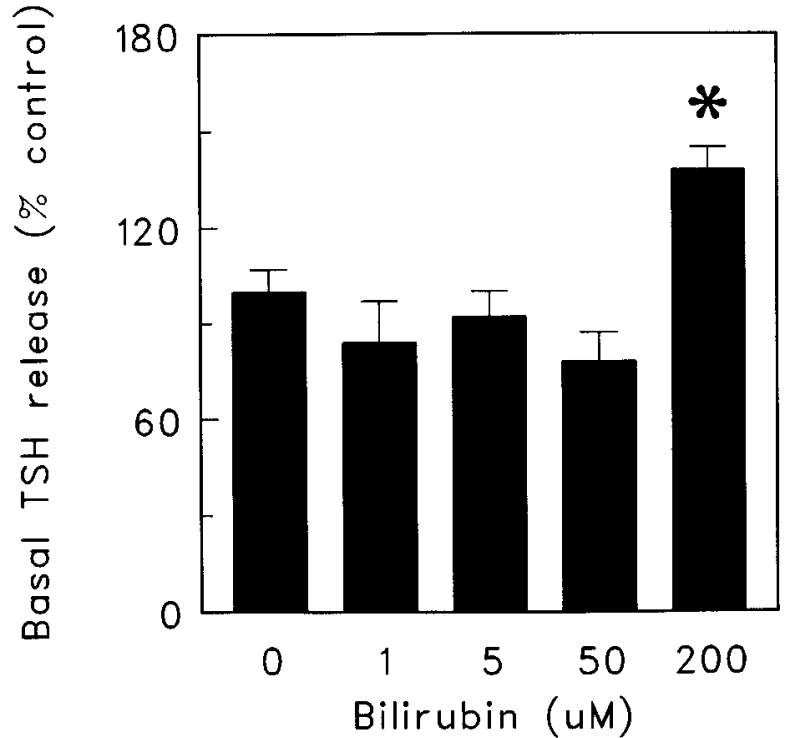

Figure 3 Effect of bilirubin $(1-200 \mu \mathrm{M})$ on basal TSH release, expressed as a percentage of the control value. Anterior pituitary cells were cultured for 3 days at a density of 400000 cells/well. Thereafter, culture medium was removed and cells were preincubated for $2 \mathrm{~h}$ in incubation medium containing $0.5 \% \mathrm{BSA}$. This medium was discarded and incubations were performed for $2 \mathrm{~h}$ in medium without or with various concentrations of bilirubin. Bars show the mean \pm S.E. of nine observations from three experiments. ${ }^{*} P<0 \cdot 05$ compared with no additions.

imental system does not reflect the physiological situation because of the absence of pituitary control factors such as dopamine, it is an appropriate model to study the role of each compound separately. Our major conclusions are: (1) $T_{3}$ uptake into the pituitary is reduced by acute ATP depletion induced by oligomycin, but not by chronic energy depletion induced by energy-poor culture conditions; (2) chronic energy depletion is not associated with changes in TSH release; (3) neither bilirubin nor biliverdin alter $\mathrm{T}_{3}$ and $\mathrm{T}_{4}$ transport into the pituitary; and (4) bilirubin does not alter basal or TRH-induced TSH release.

The effects of fasting on thyroid hormone uptake into the liver can be investigated in vivo (Van der Heyden et al. 1986, De Jong et al. 1994) or in the perfused liver (De Jong et al. 1992, 1994), and experiments with hepatocytes can be performed $4 \mathrm{~h}$ after plating (Lim et al. 1993a, b, Vos et al. 1995), but it is more complicated to study the effects of fasting on thyroid hormone uptake into the pituitary. In vivo measurements and adequate perfusion experiments are excluded for practical reasons, and studies in cultured cells require at least 2 days to permit attachment of the cells (Everts et al. 1993, 1994a, 1995a, b); consequently, effects on the pituitary induced by in vivo treatment may disappear during prolonged culture of the cells.

As an approach to examining the role of cellular energy status in $\mathrm{T}_{3}$ transport and $\mathrm{TSH}$ release in the pituitary, we 
Table 2 Effects of bilirubin $(5-200 \mu \mathrm{M})$ on TRH-induced TSH release and cellular TSH content

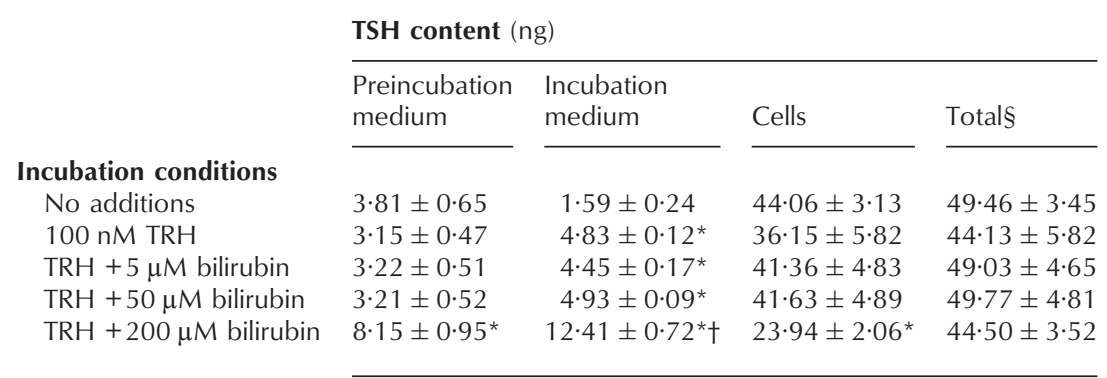

Data represent the means \pm S.E. of six observations in two independent experiments. Anterior pituitary cells (400 000 cells/well) were cultured for 3 days in medium containing $10 \%$ fetal calf serum.

Thereafter, cells were preincubated for $2 \mathrm{~h}$ in medium containing $0.5 \%$ BSA without or with bilirubin $(5-200 \mu \mathrm{M})$. Incubations were performed either in the absence of any additions or with added TRH $(100 \mathrm{nM})$ alone, or TRH $(100 \mathrm{nM})$ and bilirubin $(5-200 \mu \mathrm{M})$. TSH was measured in medium and cells by RIA. §Calculated as the sum of TSH in the two media and the cells. ${ }^{*} P<0 \cdot 05$ compared with no additions; $\uparrow P<0 \cdot 05$ compared with $100 \mathrm{nM}$ TRH.

compared the effects of long-term energy deprivation achieved by culture and incubation of the cells in the absence of glucose and glutamine with those of acute energy depletion induced by exposure to oligomycin, an inhibitor of oxydative phosphorylation. The effect of these treatments was validated by a $45-50 \%$ reduction in cellular ATP. $\mathrm{T}_{3}$ uptake was not altered under long-term energydeprived conditions, but it was significantly reduced by exposure to oligomycin. Both in cells cultured in the normal medium and in those cultured in energy-poor medium, $10 \mu \mathrm{M}$ unlabelled $\mathrm{T}_{3}$ decreased $\left[{ }^{125} \mathrm{I}_{\mathrm{T}} \mathrm{T}_{3}\right.$ uptake by around $65 \%$, without affecting the ATP content of the cells. In previous experiments (Everts et al. 1994b) in which we studied the effect of $10 \mu \mathrm{M}$ oligomycin on $\mathrm{T}_{3}$ and tri-iodothyroacetic acid transport, we found that oligomycin did indeed reduce the cellular ATP level, but that $\mathrm{T}_{3}$ transport was much more reduced than that of tri-iodothyroacetic acid transport. As the experimental conditions differed only with regard to the thyroid hormone analogue added, it is unlikely that non-specific toxicity could account for the observed effect. This is in agreement with our present observation that DNA content was not altered in presence of oligomycin.

The relation between thyroid hormone uptake and TSH release during starvation has previously been studied in vivo: in spite of the decreases in plasma $T_{3}$ and $T_{4}$ concentrations, nuclear $\mathrm{T}_{3}$ content in the pituitary was only slightly reduced and plasma TSH did not increase (St Germain \& Galton 1985). The nuclear-bound $\mathrm{T}_{3}$ in the pituitary is partly derived from the plasma $T_{3}$ and partly from intracellular conversion of $\mathrm{T}_{4}$ to $\mathrm{T}_{3}$ by type II deiodinase (Van Doorn et al. 1984), and the presence of type II but not type I deiodinase activity in cultured anterior pituitary cells has been reported (Everts et al. 1995b). Because type II deiodinase activity was diminished even in the pituitary of fasted rats (St Germain \& Galton
1985), a normal intracellular $T_{3}$ concentration could be maintained only if transport of thyroid hormone into the pituitary were enhanced.

Our experiments did not show a stimulation of $\mathrm{T}_{3}$ transport under energy-poor culture conditions. In view of the concept that $\mathrm{T}_{3}$ and $\mathrm{T}_{4}$ share a common transporter in the pituitary (Everts et al. 1994a, 1996), $\mathrm{T}_{4}$ uptake will be similarly unaffected by long-term energy deprivation. The observation that $\mathrm{T}_{3}$ transport was not altered complements our in vitro observation that TSH release remained the same under long-term energy-deprived conditions. Conversely, the fact that TSH release during energydeprived culture did not change also implies that the uptake of $\left[{ }^{125} \mathrm{I}\right] \mathrm{T}_{3}$ into the thyrotrophic cells was unaltered. This is important to note, because our measurements of $\left[{ }^{125} \mathrm{I}\right] \mathrm{T}_{3}$ uptake reflect uptake in all cell types of the pituitary.

In contrast to the effects of long-term energy deprivation ( 3 days), acute energy deprivation (i.e. exposure to oligomycin for a total of $45 \mathrm{~min}$ ) resulted in a significant reduction in $T_{3}$ uptake, indicating energy-dependence of the transport process itself. Although it has been questioned, whether oligomycin can be used to deduce information about the ATP-dependence of transport processes in intact cells (Blondeau et al. 1988), previous studies with anterior pituitary cells (Everts et al. 1993) have provided additional evidence for ATP-dependence of the $\mathrm{T}_{3}$ uptake process by its dependence on the $\mathrm{Na}^{+}$gradient (Pedersen \& Carafoli 1987) and the temperature. In hepatocytes, energy-dependence of $\mathrm{T}_{3}$ uptake was demonstrated using other metabolic inhibitors besides oligomycin (potassium cyanide and dinitrophenol; Docter \& Krenning 1990).

Whereas long-term and acute energy deprivation resulted in a similar decline in total cellular ATP content, only acute energy deprivation resulted in a reduction in $\mathrm{T}_{3}$ uptake in pituitary cells. In perfused liver, both acute 
energy depletion (De Jong et al. 1994) and prolonged fasting (De Jong et al. 1992) resulted in a decrease in thyroid hormone transport. These observations support the view that the thyroid hormone uptake mechanism is energy-dependent both in the pituitary and in the liver, whereas the long-term regulation of the thyroid hormone transport capacity in the two organs is different under conditions associated with a reduction in plasma $\mathrm{T}_{3}$ (see also Everts et al. 1996).

The concentration of bilirubin is increased in serum of critically-ill patients and was suggested as one of the factors causing the low $\mathrm{T}_{3}$ plasma concentrations in these patients, by the inhibition of $\mathrm{T}_{4}$ transport into the liver (Lim et al. 1993b). In another study, bilirubin and bilirubin derivatives were found to interfere with thyroid hormone transport in astrocytes (Chantoux et al. 1993). However, in cultured pituitary cells of the rat, neither bilirubin nor biliverdin affected $\mathrm{T}_{3}$ or $\mathrm{T}_{4}$ uptake. This again supports the view of tissue-dependent regulation of thyroid hormone transport in different cell types during NTI, and is in agreement with the concept of a common carrier for $T_{3}$ and $\mathrm{T}_{4}$ in the pituitary.

In addition, we questioned whether bilirubin also could account for the inappropriately low serum TSH level observed in critically ill patients. The presence of bilirubin $(1-50 \mu \mathrm{M})$ did not affect basal or TRH-induced TSH release; only exposure to the greatest concentration of bilirubin $(200 \mu \mathrm{M})$ resulted in a significant increase in basal and TRH-induced TSH release. The presence of $200 \mu \mathrm{M}$ bilirubin resulted in a molar ratio of bilirubin:albumin of $2 \cdot 4-$ a ratio considerably greater than that measured in normal individuals $(0.012)$ and in patients with critical illness (0.42) (Lim et al. 1993b). Therefore, the observed effect of a high bilirubin concentration could be due to some unspecific effect. Nevertheless, the observation that bilirubin does not affect pituitary function although it certainly affects liver function (Lim et al. 1993b) is in accordance with earlier reported differences concerning the effects of interleukins in liver and pituitary (Lim et al. 1993b, Wassen et al. 1996).

As the uptake of thyroid hormones is the first step in the mediation of thyroid hormone action, one could postulate that other mechanisms are involved in the maintenance of normal TSH values with low serum $\mathrm{T}_{3}$. Recently, a differential expression of thyroid hormone receptor isoforms has been found in thyrotropin-secreting pituitary tumours that could account for the altered negative feedback (Gittoes et al. 1998). This could also be the case in NTI, although in NTI patients with chronic liver disease thyroid receptor expression in the liver was not altered (Chamba et al. 1996). In a more recent paper, decreased TRH gene expression in the hypothalamus of patients with NTI was observed (Fliers et al. 1997). This may in the long run account for a reduction in the TSH concentration in NTI, but the immediate decline in TSH seems to occur before the reduction in TRH (Van
Haasteren et al. 1994). Together with a previous report of a direct effect of cytokines on TSH secretion by pituitary cells (Wassen et al. 1996), these observations lead to the conclusion that maintenance of normal TSH concentrations in NTI is achieved through an action at several levels.

In conclusion, the present study shows that thyroid hormone uptake into cultured anterior pituitary cells is not affected by long-term energy deprivation, bilirubin or its precursor biliverdin. These observations lend further support to the view that thyroid hormone transport into the pituitary is regulated differently than that in the liver. However, the fact that $T_{3}$ uptake is not stimulated under chronic energy-deprived conditions or by bilirubin cannot account for the absence of an increase in serum TSH that is observed during starvation or hyperbilirubinaemia.

\section{Acknowledgements}

The material used in the TSH assay was kindly provided by the National Hormone and Pituitary Program of the National Institute of Diabetes and Digestive and Kidney Diseases (Bethesda, MD, USA). We thank P M van Koetsveld for expert assistance.

M E Everts held a fellowship of the Royal Netherlands Academy of Arts and Sciences. The study was supported by the Trustfonds of Erasmus University Rotterdam (The Netherlands).

\section{References}

Blondeau J-P, Osty J \& Francon J 1988 Characterization of the thyroid hormone transport system of isolated hepatocytes. Journal of Biological Chemistry 263 2685-2692.

Chamba A, Neuberger J, Strain A, Hopkins J, Sheppard MC \& Franklyn JA 1996 Expression and function of thyroid hormone receptor variants in normal and chronically diseased human liver. Journal of Endocrinology and Metabolism 81 360-367.

Chantoux F, Chuniaud L, Dessante M, Trivin F, Blondeau J-P \& Francon J 1993 Competitive inhibition of thyroid hormone uptake into cultured rat brain astrocytes by bilirubin and bilirubin conjugates. Molecular and Cellular Endocrinology 97 145-151.

De Jong M, Docter R, Van Der Hoek HJ, Vos RA, Krenning EP \& Hennemann G 1992 Transport of 3,5,3'-triiodothyronine into the perfused rat liver and subsequent metabolism are inhibited by fasting. Endocrinology 131 463-470.

De Jong M, Docter R, Bernard BF, Van Der Heyden JTM, Van Toor H, Krenning EP \& Hennemann G $1994 \mathrm{~T}_{4}$ uptake into the perfused rat liver and liver $\mathrm{T}_{4}$ uptake in humans are inhibited by fructose. American Journal of Physiology 266 E768-E775.

Docter R \& Krenning EP 1990 Role of cellular transport systems in the regulation of thyroid hormone bioactivity. In The Thyroid Gland, pp 233-254. Ed MA Greer. New York: Raven Press Ltd.

Docter R, Krenning EP, De Jong M \& Hennemann G 1993 The sick euthyroid syndrome: changes in thyroid hormone serum parameters and hormone metabolism. Clinical Endocrinology 39 499-518.

Downs TR \& Wilfinger WW 1983 Fluorimetric quantification of DNA in cells and tissues. Analytical Biochemistry 131 538-547. 
Everts ME, Docter R, Van Buuren JCJ, Van Koetsveld PM, Hofland LJ, De Jong M, Krenning EP \& Hennemann G 1993 Evidence for carrier-mediated uptake of triiodothyronine in cultured anterior pituitary cells of euthyroid rats. Endocrinology 132 1278-1285.

Everts ME, Docter R, Moerings EPCM, Van Koetsveld PM, Visser TJ, De Jong M, Krenning EP \& Hennemann G 1994a Uptake of thyroxine in cultured anterior pituitary cells of euthyroid rats. Endocrinology 134 2490-2497.

Everts ME, Visser TJ, Moerings EPCM, Docter R, Van Toor H, Tempelaars AMP, De Jong M, Krenning EP \& Hennemann G $1994 b$ Uptake of triiodothyroacetic acid and its effect on thyrotropin secretion in cultured anterior pituitary cells. Endocrinology 135 2700-2707.

Everts ME, Lim C-F, Moerings EPCM, Docter R, Visser TJ, De Jong M, Krenning EP \& Hennemann G 1995a Effects of a furan fatty acid and indoxyl sulfate on thyroid hormone uptake in cultured anterior pituitary cells. American Journal of Physiology 268 E974-E979.

Everts ME, Visser TJ, Moerings EPCM, Tempelaars AMP, Van Toor H, Docter R, De Jong M, Krenning EP \& Hennemann G $1995 b$ Uptake of 3,3',5, $5^{\prime}$-tetraiodothyroacetic acid and 3,3', $5^{\prime}$ triiodothyronine in cultured rat anterior pituitary cells and their effects on thyrotropin secretion. Endocrinology 136 4454-4461.

Everts ME, De Jong M, Lim C-F, Docter R, Krenning EP, Visser TJ \& Hennemann G 1996 Different regulation of thyroid hormone transport in liver and pituitary: its possible role in the maintenance of low $T_{3}$ production during nonthyroidal illness and fasting in man. Thyroid 6 357-366.

Fliers E, Guldenaar SE, Wiersinga WM \& Swaab DF 1997 Decreased hypothalamic thyrotropin-releasing hormone gene expression in patients with nonthyroidal illness. Journal of Clinical Endocrinology and Metabolism 82 4032-4036.

Gittoes NJ, McCabe CJ, Verhaeg J, Sheppard MC \& Franklyn JA 1998 An abnormality of thyroid hormone receptor expression may explain abnormal thyrotropin production in thyrotropin-secreting pituitary tumors. Thyroid 8 9-14.

Harris ARC, Fang SL, Vagenakis AG \& Braverman LE 1978 Effect of starvation, nutriment replacement, and hypothyroidism on in vitro hepatic $\mathrm{T}_{4}$ to $\mathrm{T}_{3}$ conversion in the rat. Metabolism 27 1680-1690.

Hennemann G 1986 Thyroid hormone deiodination in healthy man. In Thyroid Hormone Metabolism, pp 277-295. Ed G Hennemann. New York: M Dekker.

Kaptein EM 1996 Thyroid hormone metabolism and thyroid disease in chronic renal failure. Endocrine Reviews 17 45-63.

Kohrle J, Hesch RD \& Leonard JL 1991 Intracellular pathways of iodothyronine metabolism. In The Thyroid, pp 144-189. Eds LE Braverman \& RD Utiger. Philadelphia: J B Lippincott.
Lim C-F, Bernard BF, De Jong M, Docter R, Krenning EP \& Hennemann G 1993a A furan fatty acid and indoxyl sulfate are the putative inhibitors of thyroxine hepatocyte transport in uremia. Journal of Clinical Endocrinology and Metabolism 76 318-324.

Lim C-F, Docter R, Visser TJ, Krenning EP, Bernard B, Van Toor H, De Jong M \& Hennemann G 1993 b Inhibition of thyroxine transport into cultured rat hepatocytes by serum of non-uremic critically-ill patients, bilirubin and non-esterified fatty acids. Journal of Clinical Endocrinology and Metabolism 76 1165-1172.

Pedersen PL \& Carafoli E 1987 Ion motive ATPases. I. Ubiquity, properties, and significance to cell function. Trends in Biochemical Sciences 12 146-150.

Sterling K \& Brenner MA 1966 Free thyroxine in human serum: simplified measurement with the aid of magnesium precipitation. Journal of Clinical Investigation 45 153-163.

St Germain DL \& Galton VA 1985 Comparative study of pituitarythyroid hormone economy in fasting and hypothyroid rats. Journal of Clinical Investigation 75 679-688.

Van Haasteren GAC, Van der Meer MJM, Hermus ARMM, Linkels E, Klootwijk W, Kaptein E, Van Toor H, Sweep CGJ, Visser TJ \& De Greef WJ 1994 Different effects of continuous infusion of interleukin-1 and interleukin-6 on the hypothalamic-hypophysialthyroid axis. Endocrinology 135 1336-1345.

Van Der Heyden JTM, Docter R, Van Toor H, Wilson JHP, Hennemann G \& Krenning EP 1986 Effects of caloric deprivation on thyroid hormone tissue uptake and generation of low- $\mathrm{T}_{3}$ syndrome. American Journal of Physiology 251 E156-E163.

Van Doorn JD, Van Der Heide D \& Roelfsema F 1984 Sources and quantity of 3,5, $3^{\prime}$-triiodothyronine in several tissues of the rat. Journal of Clinical Investigation 72 1778-1792.

Vos RA, De Jong M, Bernard BF, Docter R, Krenning EP \& Hennemann G 1995 Impaired thyroxine and 3,5,3'-triiodothyronine handling by rat hepatocytes in the presence of serum of patients with nonthyroidal illness. Journal of Clinical Endocrinology and Metabolism $\mathbf{8 0}$ 2364-2370

Wartofsky L \& Burman KD 1982 Alterations in thyroid function in patients with systemic illnesses: the 'euthyroid sick syndrome'. Endocrine Reviews 3 164-217.

Wassen FWJS, Moerings EPCM, Van Toor H, De Vrey EA, Hennemann G \& Everts ME 1996 Effects of interleukin-1 $\beta$ on thyrotropin secretion and thyroid hormone uptake in cultured rat anterior pituitary cells. Endocrinology 137 1591-1598.

Received 5 January 2000

Accepted 29 January 2000 